\title{
Characterization of extracellular polymers of Phaeocystis globosa and P. antarctica
}

\author{
Caroline M. Solomon ${ }^{1,2, *}$, Evelyn J. Lessard ${ }^{1}$, Richard G. Keil ${ }^{1}$, Michael S. Foy ${ }^{1}$ \\ ${ }^{1}$ School of Oceanography, University of Washington, Box 357940, Seattle, Washington 98195, USA \\ ${ }^{2}$ Gallaudet University, Department of Biology, 800 Florida Avenue, NE, Washington, DC 20002, USA
}

\begin{abstract}
Extracellular polymers of Phaeocystis globosa and P. antarctica were characterized by elemental analysis, X-ray photoelectron spectroscopy (XPS), and matrix-assisted laser desorption ionization - time of flight - mass spectrometry (MALDI -TOF -MS) analysis. The 2 species were grown in axenic and bacterized cultures to examine the effect of bacterial degradation on the composition of the extracellular polymers. The C:N ratios for extracellular polymers from $P$. globosa and P. antarctica grown under these conditions were lower $(<9)$ than in previous reports $(>12)$. P. antarctica polymer C:N was significantly lower than that of $P$. globosa. Contrary to expectations, the polymer C:N from bacterized cultures was slightly lower than from axenic cultures. XPS analysis indicated that the polymers are carbohydrate-rich, and MALDI-TOF-MS analysis showed that the nitrogen was not proteinaceous, but probably originated from low molecular weight compounds such as amino sugars. The low C:N ratios suggest that extracellular polymers may directly provide a substrate for bacteria and heterotrophic protists without the need for other sources of nitrogen.
\end{abstract}

KEY WORDS: Phaeocystis spp. $\cdot$ Carbohydrates $\cdot \mathrm{C}: \mathrm{N}$ ratio $\cdot$ Extracellular polymers

\section{INTRODUCTION}

Phaeocystis spp., which are colony-forming prymnesiophyte algae, produce large amounts of extracellular polymers that can contribute to the high molecular weight dissolved organic matter pool in the ocean (Lancelot 1995, Biersmith \& Benner 1998). The polymers produced during blooms can undergo sedimentation (Wassmann et al. 1990, Riebesell et al. 1995, Smith \& Dunbar 1998), or microbial degradation by heterotrophic bacteria (Janse et al. 1999) or protists capable of ingesting high molecular weight compounds (Sherr 1988, Marchant \& Scott 1993, Tranvik et al. 1993), but the biological and physical controls over these loss pathways are not well understood. Questions about the fate of these polymers are further raised by the fact that Phaeocystis blooms can result in either accumulation (i.e. North Sea: Lancelot et al. 1987) or no accumulation (i.e. Ross Sea: Carlson et al. 1998) of polymers in the dissolved organic carbon pool.
The differing degrees of microbial degradation of Phaeocystis extracellular polymers during blooms may depend on differences in the polymer chemical composition of species of Phaeocystis that thrive in distinct environments. The biodegradability of Phaeocystis polymers will in part depend on their ability to provide sufficient carbon and nitrogen to bacteria and protists. Extracellular polymers from most phytoplankton species consist primarily of carbohydrates (Guillard \& Hellebust 1971, Myklestad \& Haug 1972, Painter 1983, Hoagland et al. 1993). If the polymers also contain glycoproteins or amino sugars, they may directly provide nitrogen to microheterotrophs. On the other hand, degradation of high carbon polymers may be limited by the availability of external sources of nitrogen such as $\mathrm{NH}_{4}{ }^{+}, \mathrm{NO}_{3}{ }^{-}$or free amino acids from the surrounding seawater.

The molecular composition of extracellular polymers from Phaeocystis, as well as other phytoplankton, is not well defined. Most studies characterizing phytoplank- 
ton extracellular polymers have focused on assessing the carbohydrate fraction using bacterized cultures. The monosaccharide composition of $P$. globosa extracellular polymers consists primarily of arabinose, xylose, mannose, galactose, glucose, and rhamnose (Guillard \& Hellebust 1971, Janse et al. 1996a,b, Aluwihare \& Repeta 1999). Chitin has also been found in ejected filaments of P. globosa (Chretiennot-Dinet et al. 1997). Recently, various methods have been applied to assess the nitrogenous components of the polymers. Amide groups were detected in P. globosa colonial polymers (Hamm et al. 1999), suggesting that these have a protein or an amino sugar component.

Chemically distinct polymers may be produced by different Phaeocystis species. The C:N ratios of whole P. pouchetti colonies, consisting of both cells and extracellular polymers, vary from 4.5 to 20.5 (Verity et al. 1988, 1991, Riebesell et al. 1995, Hegarty \& Villareal 1998), whereas those of $P$. antarctica colonies vary from 5.94 to 6.22 (Moisan \& Mitchell 1999). Thus, the C:N ratio of Phaeocystis polymers may be highly variable, depending on species and growth conditions.

However, analyses of the composition of Phaeocystis extracellular polymers without the inclusion of cells are few (Biersmith \& Benner 1998, Aluwihare 1999, Aluwihare \& Repeta 1999), and are available for only 2 strains of $P$. globosa in bacterized cultures. In this study, we examined the chemical composition of axenic and bacterized extracellular polymers from another strain of $P$. globosa and from P. antarctica, which has not been previously characterized. We characterized polymers by X-ray photoelectron spectroscopy (XPS) and matrixassisted laser desorption ionization - time of flight - mass spectrometry (MALDI-TOF-MS).

\section{MATERIALS AND METHODS}

Culture conditions and isolation of extracellular polymers and polymer gels. Original stock cultures of Phaeocystis globosa (CCMP 629, isolated from the North Atlantic) and P. antarctica (isolated by E.J.L. from the Ross Sea, Antarctica) were transferred to $\mathrm{f} / 2$ media (Guillard \& Ryther 1962) with antibiotics (Provasoli's antibiotic concentrated solution, Sigma, $0.5 \%$ ) until axenic cultures were obtained. The absence of bacteria was confirmed by direct microscopic observation and the absence of bacterial growth on marine yeast-extract media (2216 marine broth, VWR Scientific Products). Axenic and bacterized cultures of $P$. globosa and $P$. antarctica were then grown in $\mathrm{f} / 10$ media $\left(177 \mu \mathrm{M} \mathrm{NO}_{3}\right.$, $\mathrm{N}: \mathrm{P}=24: 1$; Guillard \& Ryther 1962), transferred to 81 carboys containing $4 \mathrm{l}$ of $\mathrm{f} / 10$ media, and exposed to an irradiance of ca. $113 \mu \mathrm{mol}$ photons $\mathrm{m}^{-2} \mathrm{~s}^{-1}$ (ranging from 107 to $119 \mu \mathrm{mol}$ photons $\mathrm{m}^{-2} \mathrm{~s}^{-1}$ in the carboys) on a $14 \mathrm{~h}$ light:10 h dark cycle at 18 and $4{ }^{\circ} \mathrm{C}$, respectively. Bacterial strains which had been isolated from cultures of each species were added to axenic cultures for the bacterized treatment (Strain 18-18 in P. globosa cultures, Strain 4-4 in P. antarctica cultures; bacteria isolated by E. Peele). Both bacterial strains were capable of growing on Phaeocystis polymers without added nitrogen or carbon sources (E. Peele \& E. J. Lessard unpubl.). Samples of $10 \mathrm{ml}$ were taken daily for determination of phytoplankton and bacterial cell numbers. Fixative $(0.5 \%$ glutaraldehyde) and the fluorescent nuclear stain DAPI (5 $\mu \mathrm{g} \mathrm{ml}^{-1}$ final concentration) were added and filtered onto $0.2 \mu \mathrm{m}$ black polycarbonate filters. The filters were placed on slides with low-fluorescing oil, and cells were enumerated using epifluorescence microscopy. The biomass of the algae and bacteria was estimated using $14.2 \mathrm{pgC} \mathrm{cell}^{-1}$ for Phaeocystis cells (Rousseau et al. 1990) and $13 \mathrm{fgC} \mathrm{Cell}^{-1}$ for bacteria cells (Ducklow 2000).

During late exponential phase, after 9 to $15 \mathrm{~d}$ incubation, the cells were separated from polymers and polymer gels $<0.2 \mu \mathrm{m}$ in size by gravity-filtering through a SuporCap ${ }^{\mathrm{TM}} 0.2 \mu \mathrm{m}$ capsule filter (Pall/Gelman Laboratories). Preliminary growth experiments under the same culture conditions indicated the onset of the stationary phase after $10 \mathrm{~d}$ in for P. globosa and after $16 \mathrm{~d}$ in for $P$. antarctica. The timing of polymer collection was designed to harvest both species of Phaeocystis at the same phase of growth under nonlimiting conditions when cells were healthy. The filtrate was allowed to sit for $3 \mathrm{~d}$ at culture temperature to allow dispersed polymers to assemble into gels. Phaeocystis polymer gels, which are hydrated polymer networks stablilized by ionic bridges, self-assemble from $<0.2 \mu \mathrm{m}$-filtered dispersed polymers on a timescale of ca. $2 \mathrm{~d}$ (Chin et al. 1996, 1998). The polymers and gels in the filtrate were then concentrated from 2-3 1 to $500 \mathrm{ml}$ (concentration factor $=4$ to 6 ) using a CH2L Amicon ultrafiltration system with a $1 \mathrm{~nm}$ pore size $(1 \mathrm{kDa}$ nominal molecular weight cut-off) regenerated cellulose spiral-wound cartridge (S1Y10), diafiltered with 2.41 deionized water with $10 \mathrm{mM} \mathrm{CaCl}_{2}$, and lyophilized. To maximize retention of polymer gels, $\mathrm{CaCl}_{2}$ was added during diafiltration to prevent the loss of $\mathrm{Ca}^{+}$, which is needed for the stability of Phaeocystis polymer gels (van Boekel 1992, Chin et al. 1998). The ultrafiltration was performed under sterile conditions (tubing and bottles were autoclaved, ultrafiltration unit and cartridge were gas-sterilized) under a laminar flow hood. Between uses, the cartridge was cleaned $(0.01 \mathrm{~N} \mathrm{NaOH}$ without pressure for $20 \mathrm{~min}$ and with pressure for $20 \mathrm{~min}$, rinsed with autoclaved Nanopure water until the $\mathrm{pH}$ was the same as autoclaved Nanopure water) and preconditioned with the sample before concentration (after Dai et al. 1998). 
Calibration of $1 \mathbf{k D a}$ cartridge. We tested the retention efficiency of the $1 \mathrm{kDa}$-regenerated cellulose cartridge using protein (gramacidin S, $1.2 \mathrm{kDa}$; Sigma) and carbohydrate (maltoheptaose, $1.15 \mathrm{kDa}$; Sigma) standards. Initial standard concentrations were about $1 \mathrm{mgC}^{-1}$ in Nanopure water. Initial samples were taken of the standard before and after preconditioning. After concentration by a factor of 4, samples were taken from the retentate (concentrated sample) and permeate (filtrate) and measured with a total organic carbon analyzer for mass balance calculations. The retention efficiency of gramicidin and maltoheptaose was 14 and $53 \%$, respectively. Most of the gramicidin and maltohepatose was either lost to the permeate (35 and $17 \%$ ) or absorbed by the cartridge membrane (52 and $29 \%$ ).

Carbon and nitrogen analysis. Triplicate aliquots of the lyophilized concentrate from each culture were analyzed for carbon and nitrogen using a Leeman Labs Model CEC440 elemental analyzer. The concentrates were 0.10 to $0.17 \% \mathrm{C}$ and 0.025 to $0.039 \% \mathrm{~N}$ by weight; the remaining material was $\mathrm{CaCl}_{2}$ from the dialysate and other salts, including $\mathrm{NO}_{3}{ }^{-}$. To determine the contribution of $\mathrm{NO}_{3}$-nitrogen to total nitrogen, triplicate aliquots of the lypholized concentrates were resuspended in Nanopure water and analyzed for $\mathrm{NO}_{3}{ }^{-}$using a Technicon AA11 autoanalyzer. We corrected the $\mathrm{C}: \mathrm{N}$ ratio of the polymers by subtracting the $\mathrm{NO}_{3}-\mathrm{N}$ from the $\mathrm{N}$ value measured by the $\mathrm{CHN}$ analyzer for a known mass of sample.

XPS. XPS can analyze several nanometers of a surface, give information on all elements and molecular environment (e.g. oxidation state), and identify organic groups (Ratner \& Castner 1997). XPS analyses were made according to Arnarson \& Keil (2001) using a Surface Science Instruments (SSI) S-Probe ESCA instrument. An aluminum $K_{\alpha} 1,2$ monochromatized X-ray source was used to stimulate photoemission, and an electron flood gun set at $4 \mathrm{eV}$ was used to minimize surface charging of the samples. The energy of the emitted electrons was measured with a hemispherical energy analyzer at pass energies of either $150 \mathrm{eV}$ (overview spectra for elemental composition) or $50 \mathrm{eV}$ (high-resolution spectra for chemical composition of carbon and nitrogen). SSI data analysis software was used to calculate the elemental compositions from the peak areas of the overview spectra and to peak-fit the high-resolution spectra with Gaussian functions. The overview spectra that included salts (data not shown), was narrowed down to $280-300 \mathrm{eV}$ to examine the $\mathrm{C}_{1 \mathrm{~s}}$ (electron) spectra. The accuracy of the elemental compositions is limited to $10 \%$ relative error due to uncertainty about the sensitivity factors used (Arnarson \& Keil 2001).

TOF-MALDI-MS. TOF-MALDI-MS can give information about polymers in their intact state, while other techniques break the polymers into smaller fragments (Holcombe et al. in press). The same polymers analyzed by XPS were run on a Bruker Reflex III TOF mass spectrometer (Bruker-Franzen) with a single probe inlet, equipped with a UV-nitrogen laser. Matrixassisted laser desorption and ionization time of flight mass-spectrometry analyses were conducted as described by Holcombe et al. (in press) using 2,5-dihydroxybenzoic acid (DHB, Aldrich) as the matrix. All spectra were acquired in the positive-ion linear reflector mode. Typically, 100 to 500 laser shots were accumulated in the resulting spectra and the attenuation setting was approximately $40 \%$. The first scan was from 100 to $100000 \mathrm{~m} / \mathrm{z}$, while the subsequent scans were in smaller groups (50000 to 100000,20000 to 100000,7000 to 500000 , followed by 100 to $1000 \mathrm{~m} / \mathrm{z}$ ). Mass calibration was performed by using singly and doubly protonated molecular ion signals of chicken egg-white lysozyme protein standard (molecular wt = $14264)$.

Statistical analysis. Data were analyzed by mixedmodel analysis-of-variance techniques (ANOVA; SAS 2001) which contain both fixed and random factors. The 3 factors were cell/polymer, species, and treatment. The mixed ANOVA also considered the 2- and 3 -factor interactions. The 2 assumptions of ANOVA techniques, homogeneity of variance and normality, were tested. The assumption of homogeneity of variance was examined using goodness-of-fit statistics and residual variance was found to be greater for Phaeocystis globosa than for $P$. antarctica. Mixed ANOVA techniques were then used to partition the residual variance into 2 residuals, 1 for each species, solving the heterogeneity of variance problem. The assumption of normality was examined and found satisfactory within species. Means of Phaeocystis species cell and polymer $\mathrm{C}: \mathrm{N}$ ratios were compared by planned contrasts.

\section{RESULTS}

\section{Growth of Phaeocystis species cultures}

Phaeocystis globosa incubated at $18^{\circ} \mathrm{C}$ grew at $0.59 \mathrm{~d}^{-1}$, and $P$. antarctica incubated at $4^{\circ} \mathrm{C}$ grew at $0.35 \mathrm{~d}^{-1}$ (Table 1, Fig. 1). The growth rates of both Phaeocystis species were slightly higher in the presence of bacteria. Bacteria (Strain 18-18) in the P. globosa culture grew at $1.73 \mathrm{~d}^{-1}$ from an initial standing stock of $7 \times 10^{3}$ cells ml ${ }^{-1}$ while bacteria (Strain $4-4$ ) in the $P$. antarctica cultures grew more slowly, at $0.44 \mathrm{~d}^{-1}$, from an initial standing stock of $7 \times 10^{2}$ cells $\mathrm{ml}^{-1}$ (Fig. 1, Table 1). In both bacterized P. globosa and $P$. antarctica cultures, bacterial biomass was $<1 \%$ of the total biomass when polymers were harvested. 
Table 1. Phaeocystis globosa and P. antarctica. Growth rates in axenic and bacterized cultures. Growth rate of Bacterial Strains 18-18 and 4-4 in the cultures are also shown

\begin{tabular}{|lccc|}
\hline Species & $\begin{array}{r}\text { Temp. } \\
\left({ }^{\circ} \mathrm{C}\right)\end{array}$ & $\begin{array}{c}\text { Phaeocystis } \\
\text { growth rate } \\
\left(\mathrm{d}^{-1}\right)\end{array}$ & $\begin{array}{c}\text { Bacteria } \\
\text { growth rate } \\
\left(\mathrm{d}^{-1}\right)\end{array}$ \\
\hline P. globosa & 18 & 0.59 & \\
P. globosa with & 18 & 0.60 & 1.73 \\
$\quad$ Bacterial Strain 18-18 & & & \\
P. antarctica & 4 & 0.35 & 0.44 \\
$P$. antarctica with & 4 & 0.37 & \\
Bacterial Strain 4-4 & & & \\
\hline
\end{tabular}
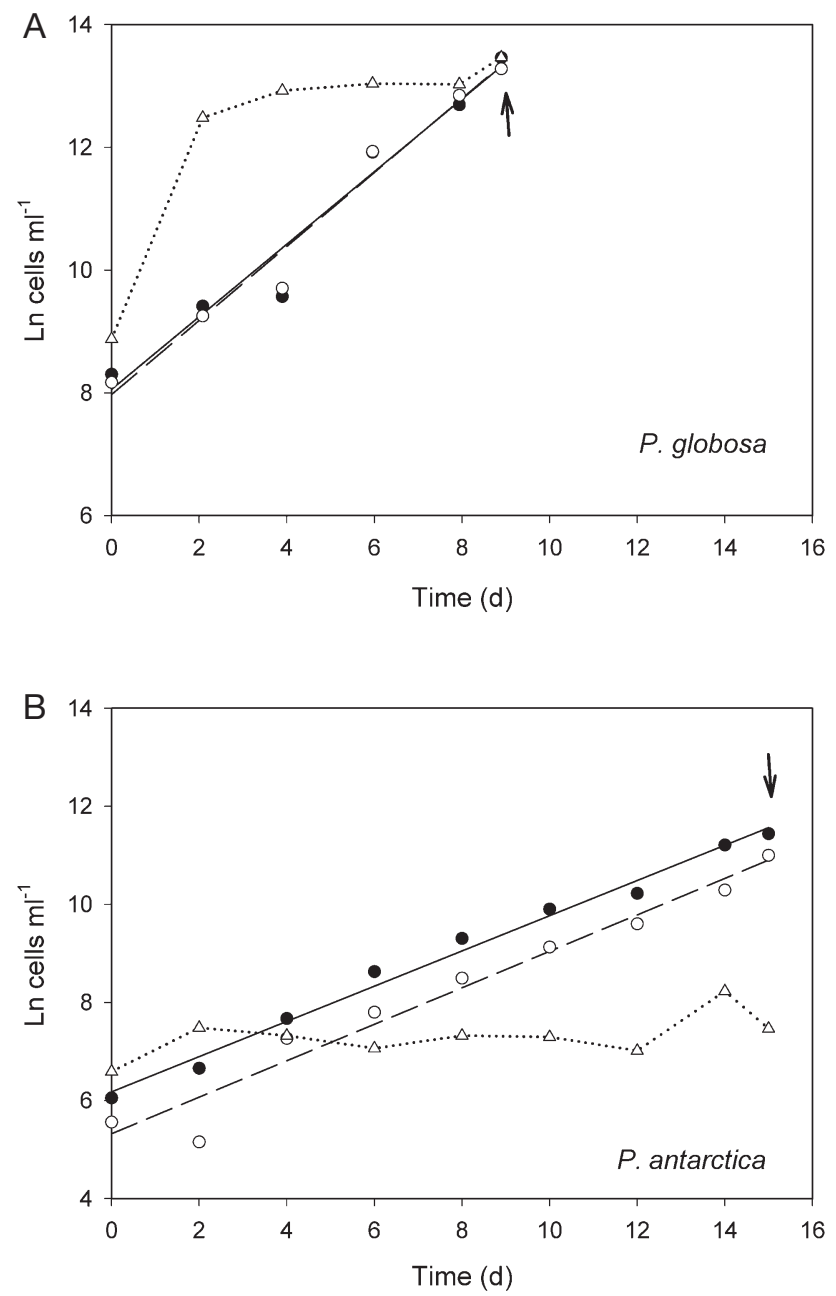

Fig. 1. Phaeocystis globosa and P. antarctica. Growth curves. (A) P. globosa $(\bullet)$ and P. globosa with Bacterial Strain 18-18 (O); growth curve for Bacterial Strain 18-18 is also shown $(\Delta)$.

(B) P. antarctica (•) and P. antarctica with Bacterial Strain 4-4 (O); growth curve for Bacterial Strain 4-4 $(\Delta)$ is also shown Arrows denote time when Phaeocystis polymers and polymer gels were collected

\section{Comparison of C:N ratios of Phaeocystis globosa and $P$. antarctica extracellular polymers and cells}

The C:N ratios of extracellular polymers from the 2 Phaeocystis species ranged from 6.20 to 8.32 (Fig. 2). The C:N ratio of $P$. globosa polymers from axenic culture was higher than those from bacterized culture (mean \pm SE: $8.32 \pm 0.28$ vs. $7.40 \pm 0.03$ ), but the difference was significant only at $p=0.07$. The $\mathrm{C}: \mathrm{N}$ ratios of polymers from axenic $P$. antarctica were significantly higher than those from bacterized cultures, but the difference $(6.86 \pm 0.03$ vs. $6.20 \pm 0.04, \mathrm{p}<0.01)$ was less than for P. globosa. P. globosa polymers had a significantly higher $\mathrm{C}: \mathrm{N}$ than $P$. antarctica polymers under both axenic and bacterized conditions $(\mathrm{p}<0.05)$. The C:N ratios of Phaeocystis cells (range 4.56 to 6.05 ) were lower than the C:N ratios of polymers. In all cultures except in the bacterized $P$. antarctica treatment, cell $\mathrm{C}: \mathrm{N}$ was significantly lower than polymer $\mathrm{C}: \mathrm{N}$ ( $\mathrm{p}<$ $0.05, P$. antarctica, $\mathrm{p}=0.2$ ). The $P$. antarctica cell $\mathrm{C}: \mathrm{N}$ of axenic and bacterized culture was significantly different $(5.22 \pm 0.10$ vs. $6.05 \pm 0.09, \mathrm{p}<0.01)$, while P. globosa cell C:N was not $(4.46 \pm 0.44$ vs. $4.99 \pm 0.32, \mathrm{p}=$ 0.36 ). The interspecific difference between cellular $\mathrm{C}: \mathrm{N}$ was significant only for the bacterized cultures $(\mathrm{p}<0.05)$.

\section{XPS and MALDI-TOF-MS}

XPS analysis indicated very little lipid $\left(\mathrm{CH}_{\mathrm{x}}\right)$ in the samples, and the spectra had a general $\mathrm{C}_{1 \mathrm{~s}}$ binding energy distribution consistent with the hypothesis that the extracellular polymers were composed

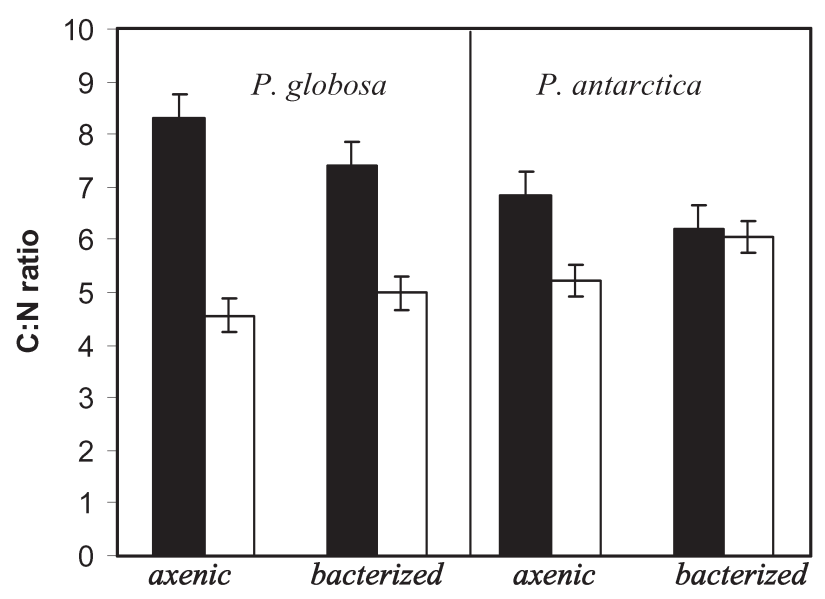

Fig. 2. Phaeocystis globosa and P. antarctica. Comparison of $\mathrm{C}: \mathrm{N}$ ratios of axenic and bacterized cultures. Black bars: polymer C:N ratios; white bars: cell C:N ratios; error bars: standard error $(n=3)$ 


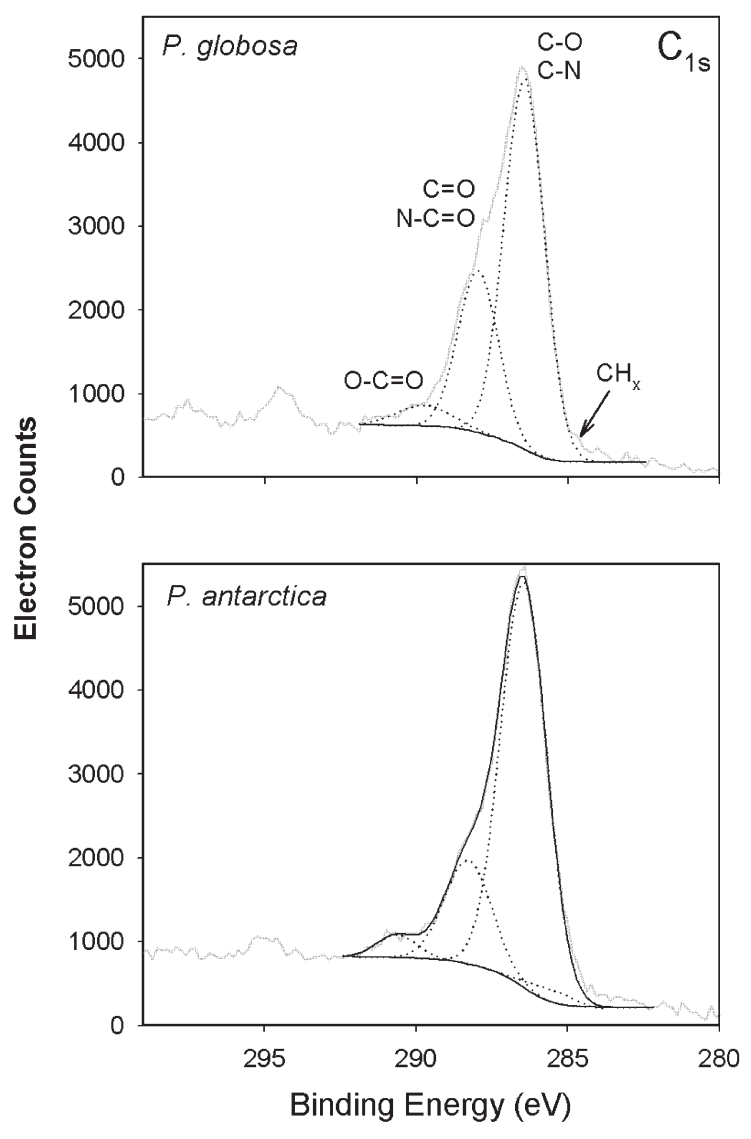

Fig. 3. Phaeocystis globosa and P. antarctica. X-ray photoelectron spectroscopy analysis of $\mathrm{C}_{1 \mathrm{~s}}$ electron peak from 280 to $300 \mathrm{eV}$ for extracellular polymers. $\mathrm{CH}_{\mathrm{x}}$ (lipid) peak set at $285.0 \mathrm{~V}$ is reference point for binding-energy scale. Chemical shift values for functional groups are as follows: $\mathrm{C}-\mathrm{N}(286.0)$, $\mathrm{C}-\mathrm{O}$ (286.5), $\mathrm{N}-\mathrm{C}=\mathrm{O}(288.2), \mathrm{C}=\mathrm{O}(288.0)$, and $\mathrm{O}-\mathrm{C}=\mathrm{O}(289.0)$ (Ratner \& Castner 1997)

largely of carbohydrates (Fig. 3). Integration of the peaks broadly assigned to the $\mathrm{C}-\mathrm{O}, \mathrm{C}=\mathrm{O}$ and $\mathrm{O}-\mathrm{C}=\mathrm{O}$ functionalities resulted in a ratio of 12:6:1. The ratio for a simple sugar (e.g. an aldose) is 5:1:0, the ratio for an amino acid is roughly 1:0:1, and the ratio for amino acids in peptides (amide bonds) is $0: 1: 1$. Given a C:N ratio of roughly 7 and assuming that the nitrogen is contained within amide bonds (as observed by Hamm et al. 1999), possible fits for the XPS spectra included mucopolysaccharides, aldoseamines, or a small glycopeptide such as $n$-glycoside.

The MALDI-TOF-MS data were consistent with the presence of carbohydrates, not proteins, in the sample (e.g. Harvey 1999). Analysis of peak distributions were done using available databases (PepFind, etc.: Holcombe et al. in press). Compounds larger than
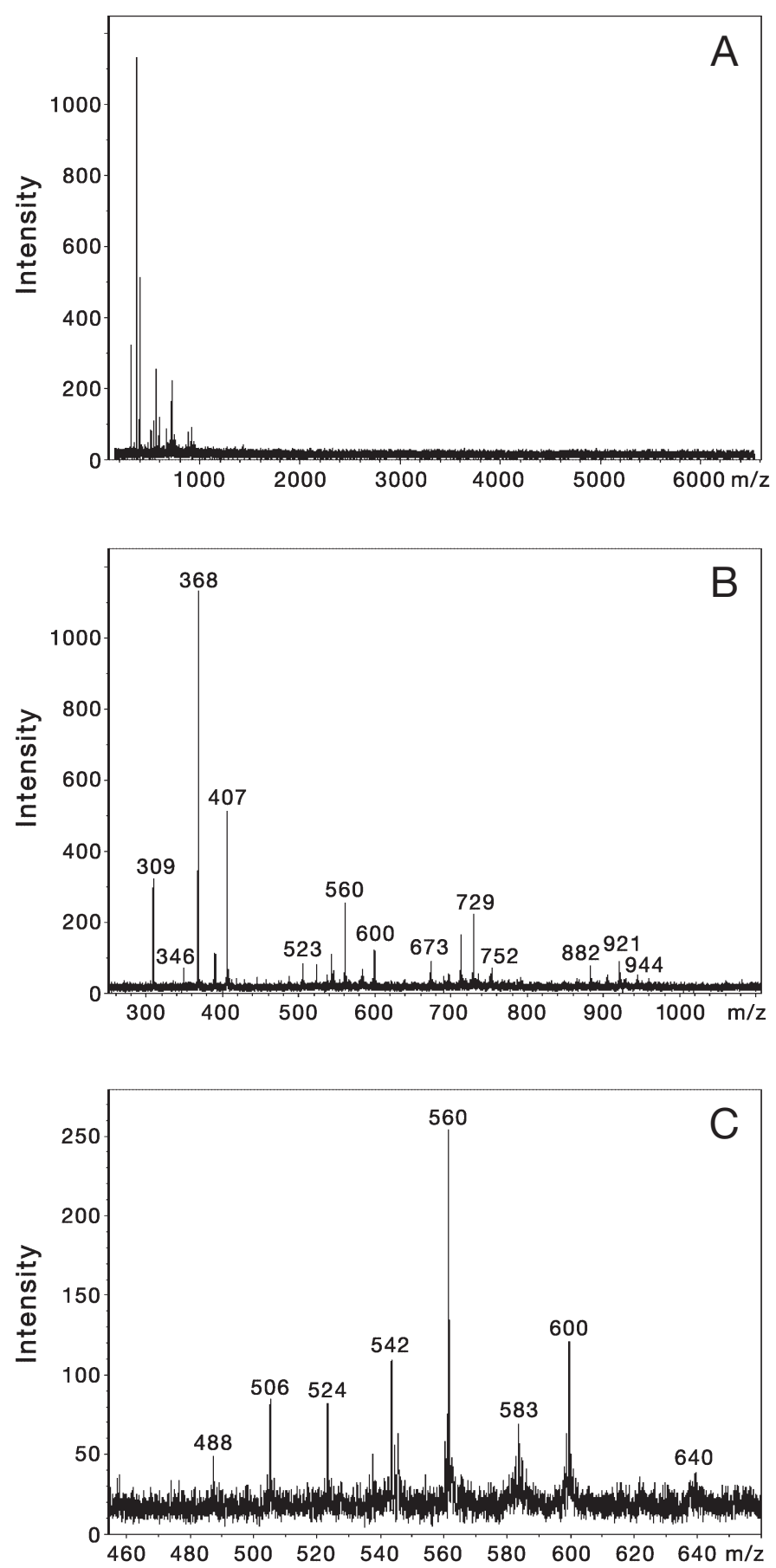

Fig. 4. Phaeocystis globosa. Matrix-assisted laser desorption ionization-time of flight-mass spectrometry spectra for extracellular polymers isolated from axenic cultures. (A) Full spectra from 100 to $7000 \mathrm{~m} / \mathrm{z}$ showing components only in the $<1000 \mathrm{~m} / \mathrm{z}$ range; spread of the 4 major clusters of peaks in the overview spectra is indicative of macromolecules with repeating structural units (i.e. carbohydrates: Harvey 1999). (B) Spectra from 250 to $1000 \mathrm{~m} / \mathrm{z}$, illustrating general pattern of approximately $\sim 192 \mathrm{~m} / \mathrm{z}$ between clusters of peaks (e.g. Peaks 368-560-752-944). (C) Spectra from 450 to $650 \mathrm{~m} / \mathrm{z}$ illustrating progressive loss of water $(18 \mathrm{~m} / \mathrm{z})$ from $\mathrm{m} / \mathrm{z} 560$ peak, sodium $(23 \mathrm{~m} / \mathrm{z})$ from $\mathrm{m} / \mathrm{z} 583$ peak, and calcium $(40 \mathrm{~m} / \mathrm{z})$ from $\mathrm{m} / \mathrm{z} 600$ peak 

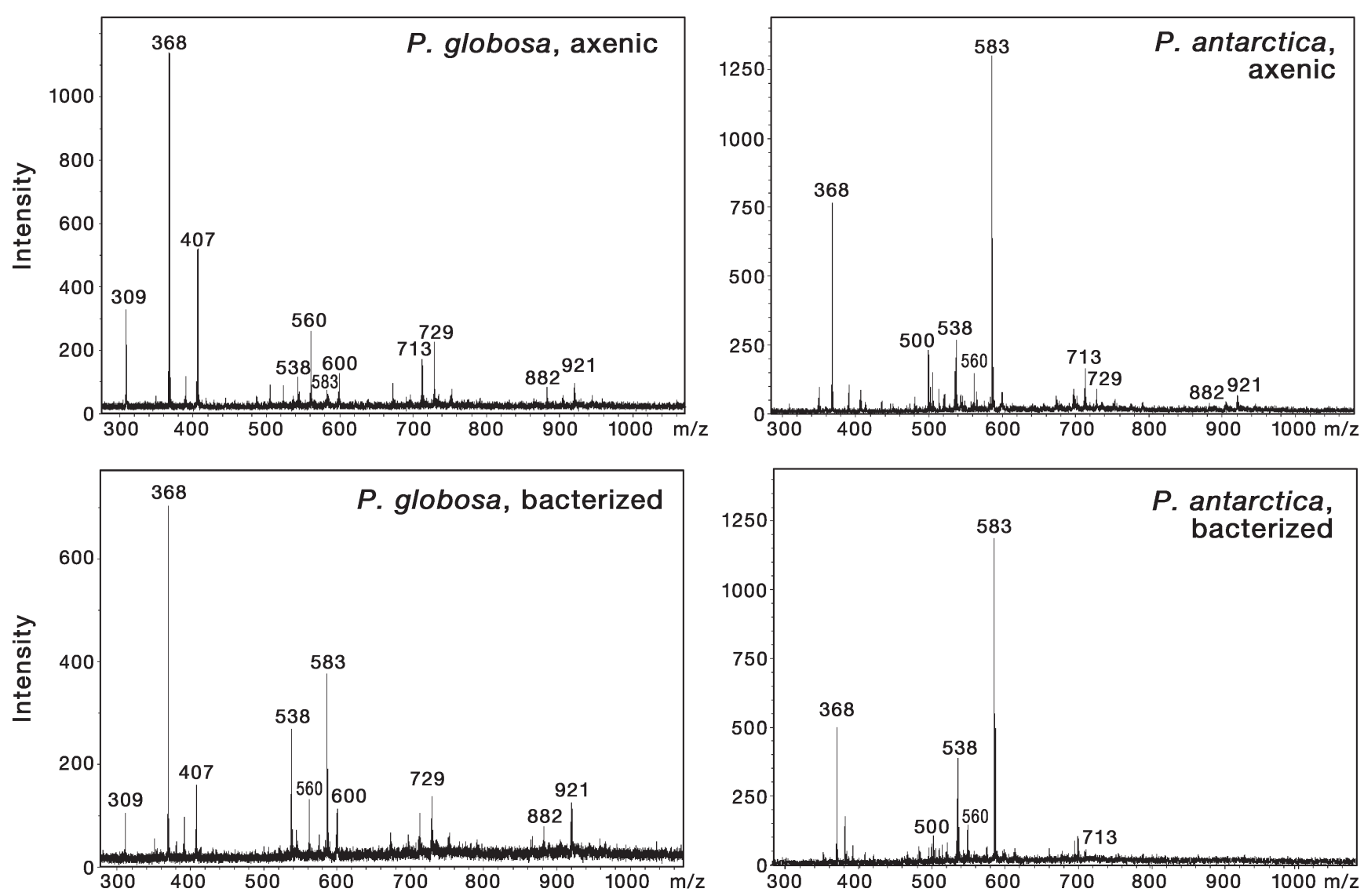

Fig. 5. Phaeocystis globosa and P. antarctica. Mass spectra in $\mathrm{m} / \mathrm{z}$ range 250 to 1100 for algae with and without bacteria present during growth

$1000 \mathrm{~m} / \mathrm{z}$ (Da) were not present, and there was a repeating pattern in the spectra (Figs. 4 \& 5). The repeating unit of $\sim 192 \mathrm{~m} / \mathrm{z}$ (Da) was close to the molecular weight of the amino sugar glucosamine (187 Da) and the initial mass of 309 was similar to that of sialic acid. Although speculative, the repeat of $\sim 190$ indicates that the polymer might not be a glycopeptide, since common bacterial glycopeptides have molecular weights between 400 and 700 and no simple way of generating repeated fragments with a $\mathrm{m} / \mathrm{z}$ of $\sim 190$. The peaks of the size $\sim 560 \mathrm{~m} / \mathrm{z}$ (Da) could represent a small polymer of 3 amino sugars $(3 \times 187=561)$. The MALDITOF-MS data also showed consistent signals of $\mathrm{Ca}^{2+}$ $(40 \mathrm{~m} / \mathrm{z}), \mathrm{Na}^{2+}(23 \mathrm{~m} / \mathrm{z})$, and $\mathrm{H}_{2} \mathrm{O}(18 \mathrm{~m} / \mathrm{z})$ from the seawater and $\mathrm{CaCl}_{2}$ additions during isolation of the polymers. This is further evidence that each of the clusters of peaks separated by $\sim 190$ units represents a carbohydrate. Polymers were present in similar compositions in both axenic and bacterized cultures of both species, although the bacterized sample of Phaeocystis antarctica did not show the presence of any peaks larger than $\sim 720 \mathrm{~m} / \mathrm{z}$.

\section{DISCUSSION}

\section{Extracellular polymer composition}

The C:N ratios of the 2 Phaeocystis species extracellular polymers obtained in this study were much lower than those previously reported for 2 other strains of $P$. globosa (19.3 and 12: Biersmith \& Benner 1998, Aluwihare \& Repeta 1999, respectively). Our relatively low $\mathrm{C}: \mathrm{N}$ ratios suggest that the extracellular polymers may contain significant amounts of protein or amino groups, and do not entirely consist of carbohydrates as suggested by many authors (Guillard \& Hellebust 1971, Painter 1983). Our results are somewhat surprising, since monosaccharides have been found to be major components of polymers by independent means such as gas chromotography, ${ }^{1} \mathrm{H}$ NMR (proton nuclear magnetic resonance), and the MBTH method (Biersmith \& Benner 1998, Aluwihare \& Repeta 1999).

Could protein potentially be an important component of Phaeocystis extracellular polymers? Amino $\left(-\mathrm{NH}_{2}\right)$ groups have been shown to be prevalent on the 
Phaeocystis colonial skin using the fluorescent probe TAMRA-SE (5-and 6-carboxytetramethylrhodamine succinimidyl ester), and hypothesized to belong to proteins (Hamm et al. 1999). In some studies of Phaeocystis extracellular polymers, the total sugar measured did not match the total carbon measured, suggesting that the unaccounted carbon may have been protein-C or glycoprotein-C (M. van Rijssel pers. comm.). Protein has also been inferred to occur in Phaeocystis extracellular polymers based on ${ }^{1} \mathrm{H}$ MNR spectra (Aluwihare \& Repeta 1999), whereby Phaeocystis globosa (CCMP 628) had small resonances from between 2.8 to $1.5 \mathrm{ppm}$, reflecting the $\mathrm{N}-\mathrm{H}$ bond (Aluwihare et al. 1997). However, our MALDI-TOF-MS data suggest that the nitrogen in Phaeocystis extracellular polymers is not from proteins or peptides but from small nitrogen-containing compounds such as amino sugars.

The MALDI-TOF-MS data showed that the extracellular polymers are present as molecules $<1000 \mathrm{Da}$ in size. This is consistent with data of Aluwihare et al. (1997), who found that a major component of natural macromolecular dissolved organic matter consisted of a chain of 7 neutral sugars of approximately $1000 \mathrm{Da}$. The molecular weights found in the MALDI-TOF-MS data may reflect glycoproteins that are cleaved at glycosidic or cross-ring bonds (Harvey 1999). The compounds most likely to produce the XPS and MALDI spectra we obtained are amino sugars, gangliosides, or sialic acid. One of the larger fragments (i.e. $921 \mathrm{~m} / \mathrm{z}$ ) may be part of a chain of 7 neutral sugars, as suggested by Aluwihare et al. (1997), whereas the other fragments may be chains of acetylated sugars and amino sugars. Therefore, nitrogen is contained in amino groups located on the sugars rather than in proteins.

\section{Possible factors contributing to differences in reported $\mathrm{C}: \mathrm{N}$ ratios}

Numerous differences between the present study and those of Biersmith \& Benner (1998) and Aluwihare \& Repeta (1999) may have contributed to the wide range of apparent $\mathrm{C}: \mathrm{N}$ ratios of Phaeocystis extracellular polymers. Possible confounding factors are the use of different Phaeocystis strains or species, different light levels for growth, different growth stages, and the presence of bacteria. Biersmith \& Benner (1998) grew P. globosa Strain CCMP 627 (from the Gulf of Mexico) at $20^{\circ} \mathrm{C}$ and ca. $100 \mu \mathrm{mol}$ photons $\mathrm{m}^{-2} \mathrm{~s}^{-1}$ in bacterized culture and measured a C:N ratio of 19 for extracellular polymers harvested during the stationary phase. Aluwihare \& Repeta (1999) grew P. globosa Strain CCMP 628 (from Vineyard Sound, Masachusetts) at $26^{\circ} \mathrm{C}$ in bacterized culture at an unspecified light level and obtained a C:N ratio of 12 for polymers in a late exponential culture. In our study, P. globosa Strain CCMP 629 (from the Gulf Stream) and P. antarctica (from the Ross Sea) were grown at 18 and $4^{\circ} \mathrm{C}$, respectively, at ca. $113 \mu \mathrm{mol}$ photons $\mathrm{m}^{-2} \mathrm{~s}^{-1}$, and were harvested at late exponential stage; their $\mathrm{C}: \mathrm{N}$ ratios were 6 to 8 . Therefore, the discrepancy between the extracellular polymer $\mathrm{C}: \mathrm{N}$ ratios recorded in different studies may be due to the use of different strains or species of Phaeocystis at different light levels or growth stages.

The membrane material of the ultrafiltration cartridge used for polymer concentration may also have affected the $\mathrm{C}: \mathrm{N}$ ratios. We used regenerated cellulose membrane cartridges, whereas Biersmith \& Benner (1998) and Aluwihare \& Repeta (1999) used a polysulfone membrane cartridge (no longer manufactured). The different materials may have different absorption characteristics for carbohydrates, proteins and amino sugars. In general, polysulfone membrane absorbs more protein than regenerated cellulose (Cheryan 1998), and this could account for the higher $C: N$ found in the previous studies. However, calibration studies with ultrafiltration cartridges using standard compounds do not portray a consistent picture about the absorption differences between the materials of the 2 cartridges. Dai et al. (1998) compared regenerated cellulose and polysulfone and found carbohydrate loss to the cartridge to be undetectable and $35 \%$, respectively, whereas protein loss was 40 to $70 \%$ and $40 \%$, respectively. Other calibration studies with $1000 \mathrm{Da}$ polysulfone cartridges (Guo \& Santschi 1996) have found lower absorption losses and better retention characteristics for Vitamin B-12 (80\%) and for various proteins (between 93 and 97\%). Aluwihare (1999) reported retention of $80 \pm 10 \%$ for carbohydrate and $50 \%$ for protein. Retention of carbohydrate and protein of the cartridge used in our study was 53 and $14 \%$, respectively, suggesting that more protein than carbohydrate was lost to the cartridge membrane. Calibration studies among polysulfone and regenerated cellulose cartridges may not be consistent but, overall, regenerated cellulose cartridges seem to absorb more protein than polysulfone cartridges. Thus, the lower $\mathrm{C}: \mathrm{N}$ found in our study is not likely to have been due to preferential absorption of carbohydrates by the regenerated cellulose cartridge.

\section{Influence of bacterial degradation on $\mathrm{C}: \mathrm{N}$ ratios of extracellular polymers}

Phaeocystis spp. extracellular polymers have been shown to effectively broken down by bacteria, but some fraction remains undegraded (Janse et al. 1999, Orellana et al. 2001). Since bacteria can degrade 
Phaeocystis extracellular polymers, they could affect the $\mathrm{C}: \mathrm{N}$ ratio of the recovered polymers during culture growth. We hypothesized that the high C:N ratios of $P$. globosa extracellular polymers found in previous studies (Biersmith \& Benner 1998, Aluwihare \& Repeta 1999) may have been due to the presence of bacteria in the experimental cultures. Even if only a low percentage of total dissolved organic carbon (DOC) is degraded, bacterial degradation could result in an increase in the $\mathrm{C}: \mathrm{N}$ ratio of residual organic matter if relatively higher amounts of dissolved organic nitrogen are utilized. It is possible that the relatively high C:N ratios (>12) of Phaeocystis polymers reported in the previous studies may have been due to preferential dissolved organic nitrogen (DON) uptake by bacteria, even though bacterial biomass was $<2 \%$ of the total DOC.

To test this, we compared the $\mathrm{C}: \mathrm{N}$ ratios of recovered polymers in axenic and bacterized cultures. Although we expected to see a higher $\mathrm{C}: \mathrm{N}$ in bacterized cultures, the $\mathrm{C}: \mathrm{N}$ ratios were actually somewhat lower in the presence of bacteria. The greater decline in $\mathrm{C}: \mathrm{N}$ for Phaeocystis globosa than for P. antarctica (8.3 to 7.3 vs. 6.8 to 6.2 ) may have been due to the larger standing stock and higher biomass production of bacteria. Bacterial degradation of diatom extracellular polymers has also reported to result in lowered $\mathrm{C}: \mathrm{N}$ ratios (as low as 5.6: Aluwihare \& Repeta 1999). How might bacteria decrease the C:N ratio? One possibility is that bacterial extracellular enzymes such as proteases and betaglucosidases (Martinez et al. 1996, Vetter \& Deming 1999) may be released during growth. Another possibility is that bacteria may have utilized the residual nitrate in the cultures and had a net excretion of DON. In our experiments, there was excess nitrate at the time of harvest, so it is unlikely that nitrate was limiting. In the Biersmith \& Benner (1998) study, total DIN reached almost zero towards the end of the experiment (Biddanda \& Benner 1997), so bacteria may have had a net uptake of DON, increasing the C:N ratios of the Phaeocystis spp. polymers. The contribution of bacteria to altering the C:N ratio of Phaeocystis extracellular polymers needs to be further investigated.

\section{Conclusion}

The C:N ratios of extracellular polymers produced by Phaeocystis globosa (CCMP 629) and P. antarctica during late exponential growth were relatively low, ranging from 6 to 8 . XPS and MALDI-TOF-MS analyses showed that the nitrogeneous component was not due to proteins but possibly to small nitrogen-containing compounds such as amino sugars. Other studies have also shown that amino acids comprise a small percent- age of dissolved organic nitrogen in the high molecular weight pool (Mannino \& Harvey 2000).

Surprisingly, the C:N ratio of Phaeocystis extracellular polymers in bacterized cultures was lower than that in axenic cultures. It is possible that released bacterial enzymes or excretion of DON by bacteria contribute to the organic nitrogen fraction of the recovered polymers. $P$. antarctica polymers are more nitrogen-rich than those of $P$. globosa, which may make them more biodegradable and may be a contributing reason to the low accumulation of DOC in the Ross Sea compared to the North Sea. In conclusion, freshly produced dissolved organic matter from phytoplankton may be a source of nitrogen as well as carbon for heterotrophic bacteria and protists. The nitrogenous component of low and high molecular weight DOM as well as the bacterial degradation of polymers need to be further investigated.

Acknowledgements. We would like to thank Thor Arnarson, Angela Norbeck and Brook Holcombe for running the XPS and TOF-MALDI-MS analysis, respectively. This study was supported by DOE Biological Investigations-Ocean Margins Program (BI-OMP), grant number DE-FG03-98ER62532.

\section{LITERATURE CITED}

Aluwihare LI (1999) High molecular weight (HMW) dissolved organic matter (DOM) in seawater: chemical structure, sources, and cycling. PhD thesis, Massachusetts Institute of Technology, Cambridge, MA

Aluwihare LI, Repeta DJ (1999) A comparison of the chemical characteristics of oceanic DOM and extracellular DOM produced by marine algae. Mar Ecol Prog Ser 186:105-117

Aluwihare LI, Repeta DJ, Chen RF (1997) A major biopolymeric component to dissolved organic carbon in surface sea water. Nature. 387:166-169

Arnarson TS, Keil RG (2001) Organic-mineral interactions in marine sediments studied using density fractionation and X-ray photoelectron spectroscopy. Org Geochem 32: 1401-1415

Biddanda B, Benner R (1997) Carbon, nitrogen, and carbohydrate fluxes during the production of particulate and dissolved organic matter by marine phytoplankton. Limnol Oceanogr 42:506-518

Biersmith A, Benner R (1998) Carbohydrates in phytoplankton and freshly produced organic matter. Mar Chem 63: 131-144

Carlson CA, Ducklow HW, Hansell DA, Smith WO (1998) Organic carbon partitioning during spring phytoplankton blooms in the Ross Sea polyna and the Sargasso Sea. Limnol Oceanogr 43:375-386

Cheryan M (1998) Ultrafiltration and microfiltration handbook. Technomic Publishing Company, Lancaster, PA

Chin W, Orellana MV, Verdugo P (1996) Exocytosis in Phaoecystis pouchetii: Donnan mechanism of swelling of exocytosed polymer gels. EOS Trans Am Geophys Un $76: 75$

Chin WC, Orellana MV, Verdugo P (1998) Spontaneous assembly of marine dissolved organic matter into polymer gels. Nature 391:568-572 
Chretiennot-Dinet MJ, Giraud-Guille MM, Vaulot D, Putaux JL, Saito Y, Chanzy H (1997) The chitinous nature of filaments ejected by Phaeocystis (Prymnesiophyceae). J Phycol 33: 666-672.

Dai M, Buesseler KO, Ripple P, Andrews J, Belastock RA, Gustafsson O, Moran SB (1998) Evaluation of two crossflow ultrafiltration membranes for isolating marine organic colloids. Mar Chem 62:117-136

Ducklow H (2000) Bacterial production and biomass in the oceans. In: Kirchman DL (ed) Microbial ecology of the oceans. Wiley-Liss, New York, p 85-120

Guillard RRL, Hellebust JA (1971) Growth and the production of extracellular substances by two strains of Phaeocystis poucheti. J Phycol 7:330-338

Guillard RRL, Ryther JH (1962) Studies on marine planktonic diatoms. I. Cyclotella nana Hustedt and Dentonula conferacea (Cleve) Gran. Can J Microbiol 8:229-239

Guo L, Santschi PH (1996) A critical evaluation of the crossflow ultrafiltration technique for sampling collodial organic carbon in seawater. Mar Chem 55:113-127

Hamm CE, Simson DA, Merkel R, Smetacek V (1999) Colonies of Phaeocystis globosa are protected by a thin but tough skin. Mar Ecol Prog Ser 187:101-111

Harvey DJ (1999) Matrix-assisted laser desorption/ionization mass spectrometry of carbohydrates. Mass Spectrom Rev 18:349-451

Hegarty SG, Villareal TA (1998) Effects of light level and $\mathrm{N}: \mathrm{P}$ supply ratio on the competition between Phaeocystis cf. pouchetii (Hariot) Lagerheim (Prymnesiophyceae) and five diatom species. J Exp Mar Biol Ecol 226: 241-258

Hoagland KD, Rosowski JR, Gretz MR, Roemer SC (1993) Diatom extracellular polymeric substances: function, fine structure, chemistry and physiology. J Phycol 29: $537-566$

Holcombe B, Norbeck A, Keil RG (in press) Hydrolysis patterns and the production of peptide intermediates during protein degradation in marine systems. Mar Chem

Janse I, van Rijssel M, Gottschal JC, Lancelot C, Gieskes WWC (1996a) Carbohydrates in the North Sea during spring blooms of Phaeocystis: a specific fingerprint. Aquat Microb Ecol 10:97-103

Janse I, van Rijssel M, van Hall P, Gerwig GJ, Gottschal JC, Prins RA (1996b) The storage glucan of Phaeocystis globosa (Prymnesiophyceae) cells. J Phycol 32:382-387

Janse I, van Rijssel M, Ottema A, Gottschal JC (1999) Microbial breakdown of Phaeocystis mucopolysaccharides. Limnol Oceanogr 44:1447-1457

Lancelot C (1995) The mucilage phenomenon in the continental coastal waters of the North Sea. Sci Total Environ 165:83-102

Lancelot C, Billen G, Sournia A, Weisse T, Colijin F, Veldhuis MJW, Davies A, Wassman P (1987) Phaeocystis blooms and nutrient enrichment in the continental coastal zones of the North Sea. Ambio 16:38-46

Mannino A, Harvey HR (2000) Biochemical composition of particles and dissolved organic matter along an estuarine gradient: sources and implications for DOM reactivity. Limnol Oceanogr 45:775-788

Marchant HJ, Scott FJ (1993) Uptake of sub-micrometer par-

Editorial responsibility: Otto Kinne (Editor),

Oldendorf/Luhe, Germany ticles and dissolved organic material by Antarctic choanoflagellates. Mar Ecol Prog Ser 92:59-64

Martinez J, Smith DC, Steward GF, Azam F (1996) Variability in ectohydrolytic enzyme activities of pelagic marine bacteria and its significance for substrate processing in the sea. Aquat Microb Ecol 10:223-230

Moisan TA, Mitchell BG (1999) Photophysiological acclimation of Phaeocystis antarctica Karsten under light limitation. Limnol Oceanogr 44:247-258

Myklestad S, Haug A (1972) Production of carbohydrates by the marine diatom, Chaetoceros affinis var. willei (Gran) Hustedt. I. Effect of the concentration of nutrients in the culture medium. J Exp Mar Biol Ecol 9:125-136

Orellana M, Lessard E, Peele E, Dycus E, Foy M, Verdugo P (2001) Bacterial and protozoa degradation of biopolymers produced by Phaeocystis globosa. ASLO Annual Meeting. American Society of Limnology and Oceanography, Waco, TX, p 106

Painter TJ (1983) Algal polysaccharides. In: Aspinall EO (ed) Polysaccharides, Vol 2. Academic Press, New York, p 195-295

Ratner BD, Castner DG (1997) Electron spectrometry for chemical analysis. In: Bickerman JC (ed) Surface analysis - the principal techniques. John Wiley \& Sons, New York, p 43-98

Riebesell U, Reigstad M, Wassmann P, Noji T, Passow U (1995) On the trophic fate of Phaeocystis pouchetii (Hariot). 6. Significance of Phaeocystis-derived mucus for vertical flux. Neth J Sea Res 33:193-203

Rousseau V, Mathot S, Lancelot C (1990) Calculating carbon biomass of Phaeocystis spp. from microscopic observations. Mar Biol 107:305-314

SAS Institute (2001) SAS/STAT Online Doc, Version 8. SAS Institute, Cary, NC

Sherr EB (1988) Direct use of high molecular weight polysaccharide by heterotrophic flagellates. Nature 335:348-351

Smith WO, Dunbar RB (1998) The relationship between new production and vertical flux on the Ross Sea continental shelf. J Mar Syst 17:445-457

Tranvik LJ, Sherr EB, Sherr BF (1993) Uptake and utilization of colloidal DOM by heterotrophic flagellates in seawater. Mar Ecol Prog Ser 92:301-309

van Boekel WHM (1992) Phaeocystis colony mucus components and the importance of calcium ions for colony stability. Mar Ecol Prog Ser 87:301-305

Verity PG, Villareal TA, Smayda TJ (1988) Ecological investigations of blooms of colonial Phaeocystis pouchetti. 1. Abundance, biochemical composition, and metabolic rates. J Plankton Res 10:219-248

Verity PG, Smayda TJ, Sakshaug E (1991) Photosynthesis, excretion, and growth rates of Phaeocystis colonies. In: Sakshaug E, Hopkins CCE, Oeritsland NA (eds) Proc Pro Mare Symp on Polar Marine Ecology, Vol 10. Polar Research, Trondheim, p 117-128

Vetter YA, Deming JW (1999) Bacterial subsistence exclusively on particulate organic matter via the action of extracellular enzymes. Microb Ecol 37:86-94

Wassmann P, Vernet M, Mitchell BG, Rey F (1990) Mass sedimentation of Phaeocystis pouchetii in the Barents Sea. Mar Ecol Prog Ser 66:183-195

Submitted: June 12, 2002; Accepted: December 10, 2002 Proofs received from author(s): March 10, 2003 